\title{
A META-ANALYSIS OF DRIVING PERFORMANCE AND CRASH RISK ASSOCIATED WITH THE USE OF CELLULAR TELEPHONES WHILE DRIVING
}

\author{
Jeff K. Caird, Chip T. Scialfa \\ Department of Psychology \\ University of Calgary \\ Calgary, Alberta, Canada \\ E-mail: jkcaird@ ucalgary.ca \\ E-mail: scialfa@ ucalgary.ca
}

\author{
Geoff Ho \\ Honeywell \\ Minneapolis, Minnesota, USA \\ E-mail: gho@mn.rr.com
}

\author{
Alison Smiley \\ Human Factors North \\ Toronto, Ontario, Canada \\ E-mail: asmiley@hfn.ca
}

\begin{abstract}
Summary: This paper addresses the effects of cell phones on driving by means of a review of the literature and an analysis of scientifically credible epidemiological and driver performance studies. A total of 84 articles were obtained covering the period from 1969 to 2004. Sixty-eight articles were research papers measuring driving performance while using a cell phone and 16 articles were epidemiological studies that examined cell phone usage and their relationship to vehicular crashes. Epidemiological findings consistently showed an increase in crashes associated with use of cell phones. However, these studies did not control for exposure to cell phone use or to driving. The negative impact of cell phone usage is larger for responses to critical events than for vehicular control. Drivers responded about a quarter of a second later to stimuli in the presence of a cell phone distractor for all studies that were analyzed. Hands-free cell phones produced similar performance decrements to hand-held phones.
\end{abstract}

\section{INTRODUCTION}

Previous reviews summarizing the scientific literature on the effects of cell phones on driving do not cover the volume of research activity in the past 7 years. Goodman et al. (1997) reviewed eleven performance-based studies, two epidemiological studies, and five traffic accident databases. Most studies found that conversing on a phone affected lane-keeping, speed, headway and event detection. They concluded that cell phones negatively affect driving performance in some contexts. However, they pointed out that the magnitude of the problem is difficult to determine because crash reports rarely indicate whether a phone was in use at the time of the crash. 
In an effort to synthesize research results on cell phone safety, we focused our analysis on two primary questions:

1. Does conversation on cell phones, whether hand-held or hands-free, influence driving performance?

2. Does performance differ between hand-held and hands-free cell phones?

\section{METHOD}

\section{Literature Selection}

A total of 84 articles were obtained covering the period of 1969-2004. Sixty-eight articles were research papers measuring driving performance while using a cell phone and 16 articles were epidemiological studies that examined cell phone usage and their relationship to vehicular crashes. Some studies were published in both proceedings and peer-reviewed journals. Duplicate studies were eliminated. A number of studies were of good quality, whereas others had insufficient statistical information (e.g., t-values or F-values for critical comparisons) to allow their use in a meta-analysis. Studies that did not measure reaction time (RT), lateral, longitudinal control or speed were dropped from further consideration. Studies included in the meta-analysis are indicated by an asterisk $\left(^{*}\right)$ in the references.

There were insufficient epidemiological studies, and their methods were too diverse, to carry out a meta-analysis to answer any of the questions outlined above.

Based on a review of 22 performance studies, the subset of dependent variables used frequently enough to allow for analysis were as follows:

1. Responses to critical events, by which is meant reaction time (RT) and the probability of missing the event (e.g., a stop sign or pedestrian entering the roadway)

2. Lateral vehicular control (e.g., average lane position, variability of lane position)

3. Longitudinal control (e.g., headway distance)

4. Speed

\section{Effect Size}

A meta-analysis is a statistical method of combining results from studies that examine similar measures. For those questions and performance measures where there existed sufficient numbers of studies to perform a meta-analysis, the approach taken was as follows. The effect of cell phone use (irrespective of phone type) was calculated as:

$$
r_{E S}=\sqrt{\frac{t^{2}}{t^{2}+d f}}=\sqrt{\frac{F}{F+d f_{\text {error }}}}
$$

where $r_{E S}$ represents effect size, that is the size of the difference between conditions (e.g., between reaction time while talking on a cell phone vs. reaction time while not using a cell phone); $t$ and $F$ represent the value on a $t$ or $F$ distribution based on the respective test of 
statistical significance, and $d f$ represents the degrees of freedom in the error term based on the statistical test performed.

This measure of effect size (Rosenthal \& DiMatteo, 2001) was then converted to a z-score, using Fisher's r-to-z transformation. The transformation expresses an effect in standard deviation units. Thus, an effect of .5 means that the condition of interest (e.g., hand-held) differed from the control condition (e.g., hands-free) by about one-half of a standard deviation. In the behavioural sciences, an effect of 0.5 is often considered of moderate magnitude while an effect of 1 or greater is quite large. While there is no fixed minimum number of studies required for metaanalysis, if the number of studies is too small, the resulting effect size can be unstable, and vary depending on which studies are included.

\section{RESULTS}

A meta-analysis was carried out to determine the effects of cell phone use on performance. Three categories of performance were considered: RT to critical events (e.g., a vehicular incursion), driving control variability variables (i.e., lane position, headway and speed variability) and speed (i.e., mean speed).

Table 1 provides summary statistics for measures of effect for RT, driving control variability measures and speed. It is clear that the cell phone conversation and information processing tasks used to simulate the distraction of conversation interfere with performance. The largest effect is seen on RT to a variety of stimuli. The discrepancies between averages and medians are small, indicating that there are no outliers influencing the means unduly. The conservative analysis that sets to zero all non-significant effects produces a reduction in estimated effect size, which remains moderate in magnitude for the RT measures but is reduced to a small and likely nonsignificant value for the driving variables. Horrey and Wickens (2004) also found greater effect sizes for RT and smaller or non-significant effect sizes for lane-keeping and tracking measures.

Table 1. Summary statistics for effects of cell phone use on reaction time and driving variable studies

\begin{tabular}{|l|c|c|}
\hline \multicolumn{1}{|c|}{ Statistic } & Reaction Time & Driving Variables \\
\hline \multicolumn{2}{|c|}{ Ignoring Data Reported as Non-Significant } \\
\hline Average & 0.64 & 0.31 \\
\hline Standard Deviation & 0.41 & 0.18 \\
\hline Median & 0.59 & 0.30 \\
\hline N of Data Points & 28 & 16 \\
\hline \multicolumn{2}{|c|}{ Setting to Zero Non-Significant Effects and Averaging Across Measures } \\
\hline \multicolumn{2}{|c|}{0.44} & 0.23 \\
\hline Average & 0.40 & 0.23 \\
\hline Standard Deviation & 0.42 & 0.20 \\
\hline Median & 21 & 12 \\
\hline N of Data Points &
\end{tabular}


The analysis revealed that there was a small effect of cell phone usage on driving speed. Specifically, drivers tended to drive more slowly while using a cell phone. However, the average effect size was .26 and had a median of .2. Thus, relative to other measures like RT or vehicular control, the use of a cell phone does not have as large an impact on the speed at which people drive.

From the larger set of cell phone studies, 18 studies adequately reported reaction time. A study was included in the analysis if baseline and distraction reaction time means were reported in the text, a table, or could be estimated from a figure (see Caird, Lees \& Edwards, 2004). Reaction time (RT) is the most common variable used to evaluate driving performance. RT is loosely used here to include brake reaction time (BRT), as well as choice reaction time and simple reaction time in response to various types of signals that included primary events (e.g., pedestrian incursion) and secondary events (e.g., LED detection).

As shown in Table 2, drivers responded about 1/4 of a second later to stimuli in the presence of a cell phone distractor for all studies that were analyzed. At higher speeds, a quarter of a second can make a difference between striking another vehicle or a pedestrian and avoiding such a crash. Importantly, the mean RT increase for hand-held and hands-free phones was essentially the same (0.21 versus 0.20$)$.

Table 2. Mean reaction time increase, standard deviation of study means, number of studies and number of participants

\begin{tabular}{|l|c|c|c|c|}
\hline \multicolumn{1}{|c|}{ Condition } & $\begin{array}{c}\text { Mean Increase in } \\
\text { Reaction Time } \\
\text { (seconds) }\end{array}$ & $\begin{array}{c}\text { Standard } \\
\text { Deviation } \\
\text { (seconds) }\end{array}$ & $\begin{array}{c}\text { Number of } \\
\text { Studies }\end{array}$ & $\begin{array}{c}\text { Number of } \\
\text { Participants }\end{array}$ \\
\hline All Distraction Tasks & 0.23 & 0.31 & 18 & 532 \\
\hline Hand Held Phone & 0.20 & 0.17 & 4 & 132 \\
\hline Hands Free Phone & 0.21 & 0.30 & 14 & 430 \\
\hline
\end{tabular}

\section{DISCUSSION}

We considered a total of 16 epidemiological and 22 performance studies of cell phone use, and used meta-analysis and a quantitative analysis of RT to answer two questions concerning the safety of cell phone use. There were insufficient epidemiological studies to carry out a metaanalysis for any of those questions. Our findings are summarized below, based on the metaanalysis, the additional analyses of RT, and on a review of the available studies.

Does conversation on cell phones, both hand-held and hands-free, influence driving performance and crash risk?

Yes. The research to date indicates that using a cell phone while driving results in deterioration of driving performance. Both responses to critical events and the ability to maintain vehicular control are hampered. Even under the most conservative analyses, small to moderate effects exist. The negative impact of cell phone usage is larger for responses to critical events than for 
vehicular control. Driving variables, including lane position and headway variability, showed smaller effects.

The average RT increase in the presence of a cell phone distraction is about a quarter of a second. This value probably underestimates the behaviour of drivers when not being observed and who are free to adopt typical habits within their own vehicles (Caird et al., 2004). On-road driver behaviour tends to be worse than driver performance assessed in experimental settings.

The effect of conversation on driver performance is to delay recognition and response to important traffic events. To date, research suggests that hands-free cell phones produce similar performance decrements to hand-held phones. Legislation has not necessarily considered the impact that hands-free conversation has on driver performance (Caird et al., 2004).

Does performance differ between hand-held and hands-free cell phones?

No. Based on the available studies (1 epidemiological, 7 performance), the data indicate no difference between hand-held and hands-free cell phones. This conclusion is tentative, being based on only a single epidemiological study and on studies that did not measure performance in driving situations more likely to be impacted differentially by hand-held and hands-free cell phones.

\section{Gaps in Research}

In the process of reviewing 84 articles on the impact of cell phone use on driving, a number of gaps in the research became evident. These were as follows:

- Insufficient control for exposure to driving in crash studies

- Insufficient control for exposure to cell phone use, and confounding age effects

- Insufficient study of hand-held as compared to hands-free cell phones

- Lack of clarity concerning the timing of the cell phone task and a critical driving event and the performance of the cell phone task

- $\quad$ Lack of clarity regarding the meaning of reported driving performance variables with respect to changes in risk

\section{ACKNOWLEDGMENTS}

Funding for this meta-analysis was provided by the Canadian Automobile Association (CAA) Foundation for Traffic Safety to Human Factors North. Additional support for the literature and RT analyses was provided by the University of California at Berkeley/PATH to the first author. Don Szarko and Delphine Cody were the technical monitors for each of these organizations, respectively.

\section{REFERENCES}

Studies that are preceded by an asterisk $\left(^{*}\right)$ were included in the meta-analysis, whereas studies included in the quantitative RT analysis are denoted by a number sign (\#). 
\#*Ålm, H., \& Nilsson, L. (1994). Changes in driver behaviour as a function of handsfree mobile phones: A simulator study. Accident Analysis \& Prevention, 26(4): 441-451.

\#*Ålm, H., \& Nilsson, L. (1995). The effects of mobile telephone task on driver behaviour in a car following situation. Accident Analysis \& Prevention, 27(5): 707-715.

*Brookhuis, K.A., de Vries, G., \& de Waard, D. (1991). The effect of mobile telephoning on driving performance. Accident Analysis \& Prevention, 23(4): 309-316.

\#Burns, P.C., Parkes, A., Burton, S., Smith, R.K., \& Burch, D. (2002). How dangerous is driving with a mobile phone? Benchmarking the impairment to alcohol (Tech. Rep. TRL 547). Crowthorne, U.K.: Transport Research Laboratory.

\#Burns, P.C., Parkes, A.M., \& Lansdown, T.C. (2003). Conversations in cars: The relative hazards of mobile phones. Proceedings of the International Ergonomics Association Meeting [CD-ROM]. Seoul, Korea: IEA.

Caird, J.K., Lees, M., \& Edwards, C. (2004). The naturalistic driver model: A review of distraction, impairment and emergency factors. Richmond, CA: California PATH/U. of California at Berkeley.

Caird, J.K., Scialfa, C., Ho, G., \& Smiley, A. (2004). The Effects of Cellular Telephones on Driving Behaviour and Accident Risk: Results of a Meta-Anlaysis. Edmonton, AB: AMA/CAA. www.ama.ab.ca/advocacy/traffic_safety/FinalReport_CellPhones4.pdf

\#*Consiglio, W., Driscoll, P., Witte, M., \& Berg, W.P. (2003). Effect of cellular telephone conversations and other potential interference on reaction time in a braking response. Accident Analysis \& Prevention, 325: 495-500.

\#*Cooper, P.J., Zheng, Y., Richard, C., Vavrik, J., Heinrichs, B., \& Siegmund, G. (2003). The impact of hands-free message reception/response on driving task performance. Accident Analysis \& Prevention, 35: 23-35.

Goodman, M.J., Bents, F.D., Tijerena, L., Wierwille, W., Lerner, N., \& Benel, D. (1997). An investigation of the safety implications of wireless communications in vehicles (DOT HS 806635). Washington, DC: National Highway Transportation Safety Administration. http://www. nhtsa.dot.gov/people/injury/research/wireless/

*Gugerty, L., Rando, C., \& Rakauskas, Brooks, J., Olson, H. (2003). Differences in remote versus in-person communications while performing a driving task. Proceedings of the Human Factors and Ergonomics Society $47^{\text {th }}$ Annual Meeting. Santa Monica, CA: HFES: 1855-1859.

\#Hancock, P.A., Hashemi, L., Howarth, H., \& Ranney, T. (1999). The effects of in-vehicle distraction on driver response during a critical driving maneuver. Transportation Human Factors, 1(4): 295-309.

\#Hancock, P.A., Lesch, M., \& Simmons, L. (2003). The distraction effects of phone use during a crucial driving maneuver. Accident Analysis \& Prevention, 35: 510-514.

Horrey, W., \& Wickens, C. (2004). The impact of cell phone conversations on driving: A metaanalytic approach (Tech. Rep. No. AHFD-04-2/GM-04-1). Savoy, Illinois: Institute of Aviation. 
*Irwin, M., Fitzgerald, C., \& Berg, W.P. (2000). Effect of the intensity of wireless telephone conversations on reaction time in a braking response. Perceptual and Motor Skills, 90: 11301134.

*Ishida, T., \& Matsuura, T. (2001). The effect of cellular phone use on driving performance. IATSS Research, 25(2): 6-14.

\#* Laberge, J., Scialfa, C., White, C., \& Caird, J. (2004). The effect of passenger and cellularphone conversations on driver distraction. Transportation Research Record, 1899: 109-116.

\#*Lamble, D., Kauranen, T., Laakso, M., \& Summala, H. (1999). Cognitive load and detection thresholds in car following situations: Safety implications for using mobile telephone (cellular) telephones while driving. Accident Analysis \& Prevention, 31: 617-623.

*McCarley, J., Vais, M., Pringle, H., Kramers, A.F., Irwing, D.E., \& Strayer, D.L. (2001). Conversation disrupts visual scanning of traffic scenes. Vision in Vehicles. Australia.

*McPhee, L., Scialfa, C., Dennis, W., Ho, G. \& Caird, J.K. (2004). Age differences in visual search for traffic signs during a simulated conversation. Human Factors, 46(4): 674-685.

*Nilsson, L., \& Ålm, H. (1991). Elderly people and mobile telephone use-including comparisons to younger drivers' behaviour. (Rep. No. 176, DRIVE Project V1017, BERTIE). Gothenburg, Sweden: Swedish Road and Traffic Research Institute.

\#*Parkes, A.M., \& Hooijmeijer, V. (2001). Driver situation awareness and car phone use. Proceedings of the $1^{\text {st }}$ Human-Centered Transportation Simulation Conference (ISSN 15383288). Iowa City, IA: University of Iowa.

\#*Patten, C.J.D., Kircher, A., Ostlund, J., \& Nilsson, L. (2004). Using mobile telephones: Cognitive workload and attention research allocation. Accident Analysis \& Prevention, 36: 341-350.

*Rakauskas, M., Gugerty, L., \& Ward, N.J. (2004). Effects of naturalistic cell phone conversations on driving performance. Journal of Safety Research, 35: 453-464.

\#*Ranney, T., Watson, G., Mazzae, E.N., Papelis, Y.E., Ahmad, O., \& Wightman, J.R. (2004). Examination of the distraction effects of wireless phone interfaces using the National Advanced Driving Simulator-Preliminary report on freeway pilot study (Pre. No. DOT 809 737). East Liberty, OH: National Highway Transportation Safety Administration.

Rosenthal, R., \& DiMatteo, M.R. (2001). Meta-analysis: Recent developments in quantitative methods for literature reviews. Annual Review of Psychology, 52: 59-82.

\#*Strayer, D.L., \& Drews, F.A.. (2003). Effects of cell phone conversations on younger and older drivers. Proceedings of the Human Factors and Ergonomics Society $47^{\text {th }}$ Annual Meeting. Santa Monica, CA: HFES: 1860-1864

*Strayer, D.L., Drews, F.A., Albert, \& Johnston, W.A. (2002). Why do cell phone conversations interfere with driving? Proceedings of the $81^{\text {st }}$ Annual Transportation Research Board Meeting [CD-ROM]. Washington, DC: TRB.

\#Strayer, D.L., Drews, F.A., \& Crouch, D.J. (2003). Fatal attraction? A comparison of the cellphone driver and the drunk driver. Proceedings of the Second International Driving Symposium on Human Factors in Driver Assessment, Training and Vehicle Design. Park City, Utah: 25-30. 
\#*Strayer, D.L., Drews, F.A., \& Johnston, W.A. (2003). Cell phone-induced failures of attention during simulated driving. Journal of Experimental Psychology: Applied, 9(1): 23-32.

*Strayer, D.L., \& Johnston, W.A. (2001). Driven to distraction: Dual-task studies of simulated driving and conversing on a cellular telephone. Psychological Science, 12(6): 1-5.

*Tijerina, L., Kiger, S., Rockwell, T., \& Tornow, C. (1996). Heavy vehicle driver workload assessment, Task 7A: In-car text message system and cellular phone use by heavy vehicle drivers on the road (Rep. No. DOT HS 808467 7A). Washington, DC: NHTSA.

\#Tokunaga, R.A., Hagiwara, T., Kagaya, S., \& Shimojyo, A. (2000). Cellular telephone conversation while driving: Effects on driver reaction time and subjective mental workload. Transportation Research Record, 1724, 1-6. 